\title{
PATHOMORPHOLOGICAL CHANGES IN THE SKIN OF THE GUINEA PIGS IN THE COURSE OF MICROSPORES
}

\author{
Iaroslav Kisera ${ }^{1}$ \\ kisera53@ukr.net \\ Yulya Martyniv ${ }^{1}$ \\ Juliamartyniv8@gmail.com \\ Ivan Klishch \\ Ternopil National Medical University namedafter I. Gorbachevskogo \\ 1 Voly sq., Ternopil, Ukraine, 46001 \\ klishch@tdmu.edu.ua
}

${ }^{1}$ Stepan Gzhytskyi National University of Veterinary Medicine and Biotechnologies Lviv 50 Pekarskaya str., Lviv, Ukraine, 79010

\begin{abstract}
During the course of microspores on the skin, the balance between the species of saprophytic microorganisms and hypersensitivity as an integral part of the inflammatory reaction resulting from the presence of the pathogen in the skin is disturbed. The degree of expression of inflammation varies. Clinical manifestations of microsporia are manifested by erythema, alopecia, scaly and crust formation.

The aim. Histological studies were performed to determine pathomorphological changes in the skin of guinea pigs during microsporia. The studies were conducted on clinically healthy and sick guinea pigs during the acute course of the disease, during regeneration and during recovery.And also carry out a description and characterization of the identified changes in the skin.The obtained research results showed that patients with microsporia had changes in the morphological composition of the skin, which were characterized by thickening and keratinization of the epidermis, there were small-focal polymorphic cell infiltrates, there was a violation of the microvasculature and the formation of micellar formations.

Materials and methods. The material for histological examination(pieces of guinea pig skin) was fixed in a $10-12 \%$ cooled solution of neutral formalin, followed by pouring into paraffin according to the scheme proposed by G.A. Merkulov (1969). Histomic sections 5-7 $\mu \mathrm{m}$ thick were made on the MC-2 dome microtome. Hematoxylin and eosin staining were used for the morphological evaluation of cells and tissue. Microscopy was performed using an OLIMPUS CX-41 microscope.

Results. Signs of superficial inflammation with hyperkeratosis and desquamation of cells of the stratified epithelium, microcracks of the epidermis were found in the skin of the patient with microsporia of the tentacle during the acute course. Signs of inflammation of the follicles and surrounding tissues are visualized. Round-cell and plasma connective tissue infiltrates of the connective tissue of the skin were detected by lymphoid, histiocytic and other cellular elements. There is moderate leukocyte infiltration in the dermis. Signs of inflammation by type of infiltration around the hair follicles, enlargement of the blood capillaries and the presence of microabscesses.

In the stage of regeneration during recovery, a clear contoured layer of epithelial cells is established. There are no signs of inflammatory reaction in the dermis.

Conclusion. In microspores, inflammatory processes occur in all layers of the skin. The skin of sick animals loses its barrier function due to pathomorphological changes. The long-term consequences of the pathological process during the course of microspores can provoke the development of chronic dermatitis with scleroderma.
\end{abstract}

Keywords: guinea pig, microsporia, skin, epidermis, dermis, hypodermis, inflammation, keratinization, regeneration.

DOI: $10.21303 / 2504-5679.2020 .001124$

\section{Introduction}

Skin is an epithelial-connective tissue organ of an animal's body that performs barrier function. It communicates the body with the environment, protects the body from mechanical, thermal, chemical and other exogenous factors, as well as from penetration into the body of various macro- and microorganisms $[1,2]$. The skin surface has both antibacterial and antifungal properties. This, in combination with its immunoregulatory function, prevents the development of infections [3, 4]. 
The structure of the skin is the same and consists of the epidermis, dermis and hypodermis. The epidermis is the outer layer of the animals skin [5,6]. Its main function is to protect the internal organs from external influences [7]. The epidermis is constantly updated. New skin cells develop at the base of the epidermis and migrate upwards - this process is called keratinization. As a result, a dense protective layer is formed on the skin surface of the dead cells. This layer is capable of resisting the influence of water and other liquids, salts, various substances, to protect the body from getting into it infection, etc. The outer layer of dead skin cells is gradually removed from the skin and replaced by the cells below it. The speed of skin recovery depends on nutrition, hormonal system, body tissues, immune system and genetic features. Diseases and inflammatory processes also affect the growth and cleavage processes of epidermal cells.

The area of the basal membrane of the skin is located at the base of the epidermis and connects it with the middle layer of skin located below - the dermis. This layer also acts as a protective barrier between the epidermis and the dermis. Some skin disorders, including autoimmune, can be a danger to the basement membrane area $[8,9]$.

Dermis - the middle layer of the skin supports and nourishes the epidermis and skin appendages. It is in the dermis that there is a network of blood vessels that supply nutrients to the epidermis $[10,11]$. The blood vessels in the dermis are also responsible for regulating body and skin temperature. Sensory nerve endings are located in the dermis and hair follicles, whereby the skin responds to touch, pain, itching, and is able to feel the heat and cold. The dermis produces collagen and elastin proteins, which give the skin its elasticity. The dermis also contains cells of the immune system that protect the body from infectious agents that penetrate the outer layer of the skin.

The hypodermis is the inner layer of the skin. It contains subcutaneous fat and muscle. The main muscles by which the animal trembles from the cold are located directly under the skin. Subcutaneous fat provides thermal insulation, stores fluid, electrolytes, and energy, and provides some shock absorption during collisions [12].

The course of microspores on the skin disrupts the balance between species of saprophytic microorganisms and hypersensitivity as an integral part of the inflammatory response resulting from the presence of the pathogen in the skin [13]. The degree of expression of inflammation varies. Clinical manifestations of microsporia are manifested by erythema, alopecia, scaly and crust formation [14]. The skin at the foci of inflammation becomes rough, the animal intensely combing the lesions, which provokes the appearance of saddens resulting in damage not only to the epidermis, but also to the dermis of the dermis. Owing to the increased desquamation of the stingy epithelium, it is excessively cohesive in the form of light gray pulverized mass to the disappearance of whole layers [12]. However, the skin defect heals without scar formation, but secondary pyoderma may occur and as a result of impaired skin immune function as an organ.

Attention should be paid to the factors that tend to infect animals with microsporia: viral infections; neoplasm; poor feeding; treatment with anti-inflammatory immunity suppressants, especially progestogens; pregnancy; systemic diseases; ectoparasitic diseases $[15,16]$. Microsporia can occur as a single disease or as a complication of other dermatological pathologies of bacterial, allergic or parasitic genesis. In the course of microspores, the organism in immunosuppressive state is exposed to the pathogenic influence of the pathogen Microsporum, which additionally deprives the skin of its barrier function [17].

The conducted research gives an opportunity to estimate morphological changes in the structure of skin layers in healthy and with microsporic guinea pigs during acute course of the disease and during the period of regeneration during recovery.

The aim of the study was to investigate the histological structure of the skin in healthy guinea pigs and ones with microsporic. Describe pathomorphological changes in the skin with microsporia. To compare the structure of the skin in healthy and sick animals at different stages of the disease.

\section{Materials and methods of research}

The material for the study was collected at a private veterinary clinic "Impulse" in the city of Lviv in Guinea pigs with microsporium in the acute course and recovery. The skin of a healthy 
animal in the vivarium of the Stepan Gzhytskyi National University of Veterinary Medicine and Biotechnologies Lviv was taken in order to conduct control. Histological examinations were performed in the laboratory of clinical and biological research of the State Scientific Research Institute of Veterinary Drugs and Feed Additives, Lviv.

The experiment complies with the ARRIVE guidelines. And it was conducted in accordance with the UK Animal Science (Scientific Procedures) Act 1986 and the relevant guidelines.

The material for histological examination (pieces of skin) was fixed in a 10-12\% cooled solution of neutral formalin, followed by pouring into paraffin according to the scheme proposed by G. A. Merkulov (1969). The fixed pieces of $2 \mathrm{~mm}$ thick were washed in water for $30 \mathrm{~min}$. and more, then dried on filter paper and passed through alcohols (75, 96 and $100^{\circ}$ for dehydration and degreasing in each alcohol for 24 hours). Then it was penetrated with paraffin solvent with xylene for 1.5 hours. The pieces were transferred from the xylene to a saturated paraffin solution in xylene for 1.5 hours. at a temperature of $37^{\circ} \mathrm{C}$. Then the pieces were kept in molten paraffin at a temperature of $54-55^{\circ} \mathrm{C}$, i. e. at a temperature in $2-3^{\circ}$ higher than the melting point of paraffin, up to 2 hours in the first portion of paraffin and up to 2 hours in the second. Then they were transferred to porcelain cups and poured with molten paraffin, followed by rapid cooling in the refrigerator. After paraffin hardening, the pieces were cut into paraffin and glued to wooden cubes. Histomic sections 5-7 $\mu \mathrm{m}$ thick were made on the MC-2 dome microtome. Hematoxylin and eosin staining were used for the morphological evaluation of cells and tissue [17].

Microscopy was performed using an OLIMPUS CX-41 microscope.

\section{Results}

Studies have shown that the histological structure of the skin of a healthy Guinea pig was without pathological changes. The epidermis is represented by a multilayered flat ciliated epithelium. The basal layer is preserved and consists of cylindrical cells. The spiny, granular and horny layer formed by horny scales was also very visible. The dermis is represented by bundles of elastic and collagen fibers with the presence of histiocytes, fibroblasts (Fig. 1-3), constructed of papillary and reticular layers. Collagen fibers are assembled into bundles of different shapes and thicknesses. Layers of loose thin-fiber fabric are placed in separate beams. The hypodermis is represented by a loose connective tissue between the bundles of which fibroblasts, histiocytes, and fat cells are placed, which, when stained, are defined as transparent cellular structures.

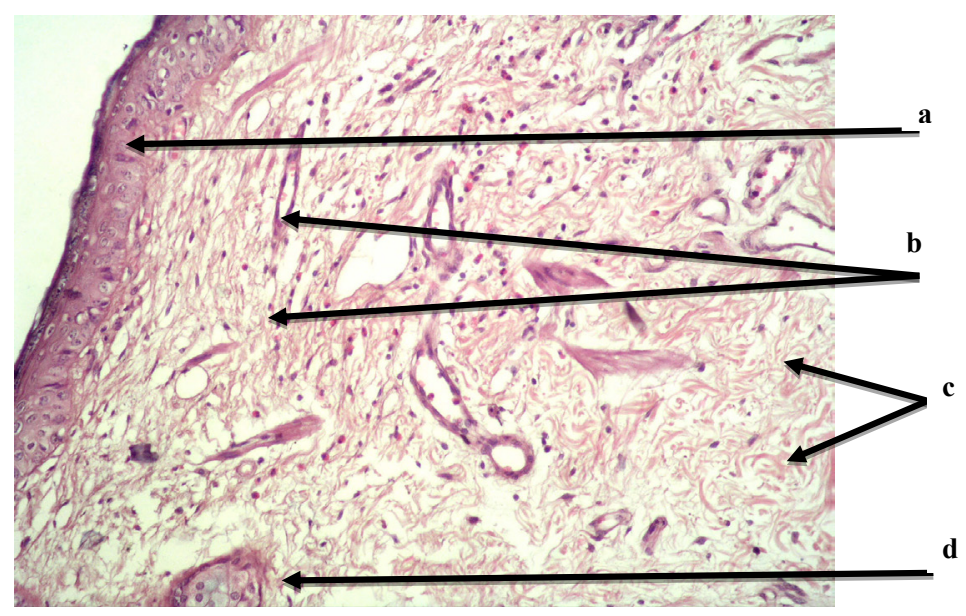

Fig. 1. The skin of a healthy tent:

$\mathrm{a}$ - epidermis; $\mathrm{b}$ - dermis; $\mathrm{c}$ - hypodermis; $\mathrm{d}$ - sebaceous gland. Hematoxylin and eosin.

EG. 10, vol. 10

In the skin of the Guinea pig with microsporia during acute course, signs of superficial inflammation with hyperkeratosis and desquamation of cells of the stratified epithelium, microcracks of the epidermis were revealed (Fig. 4-6). 


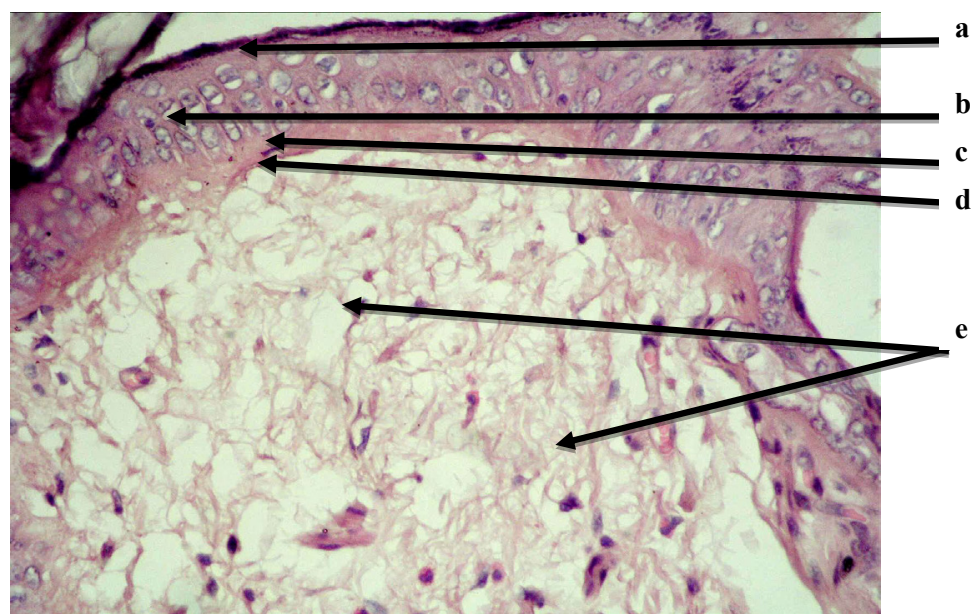

Fig. 2. The skin of a healthy Guinea pig:

$\mathrm{a}$ - horn layer; $\mathrm{b}$ - granular layer; c -spiked layer; $\mathrm{d}$ - basal membrane; derma.

Hematoxylin and eosin. EG. 10, vol. 40

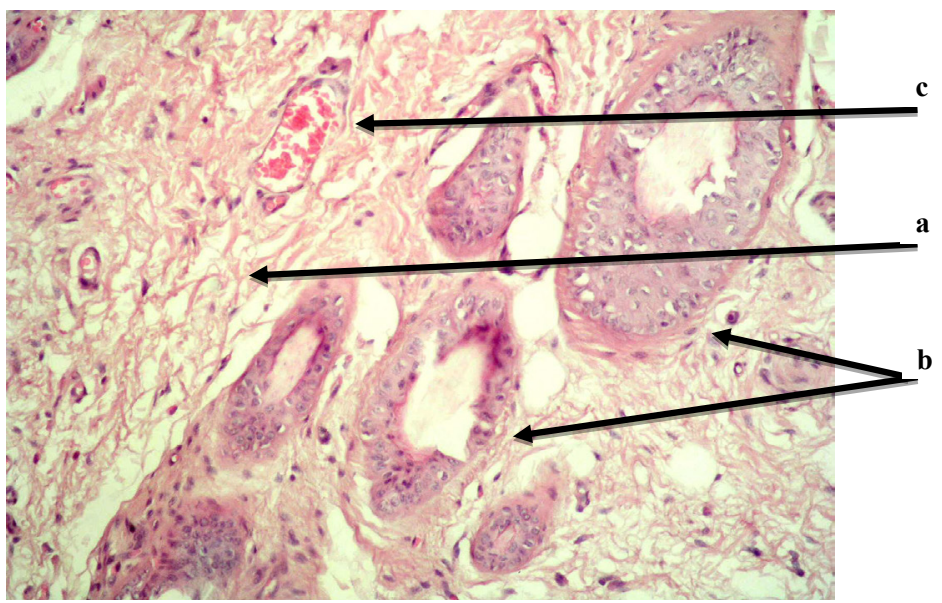

Fig. 3. The skin of a healthy Guinea pig:

$\mathrm{a}$ - the dermis; $\mathrm{b}$ - white hair follicles; $\mathrm{c}$ - blood vessels. Hematoxylin and eosin. EG. 10, vol. 40

Signs of inflammation of the follicles and surrounding tissues are visualized. Roundcell and plasma connective tissue infiltrates of the connective tissue of the skin were detected by lymphoid, histiocytic and other cellular elements. There is moderate leukocyte infiltration in the dermis (Fig. 7, 8). There are also signs of inflammation by the type of infiltration around the hair follicles, enlargement of the blood capillaries and the presence of microabscesses (Fig. 9).

Active hyperemia of the papillary layer, varying degrees of edema and loosening in the dermis was established. The epithelium of the follicles is swollen, the growth of sebaceous glands with active proliferation and differentiation of cells is noted (Fig. 10).

Histological examination of the skin of ill animals in the stage of regeneration revealed a clear contoured layer of epithelial cells (Fig. 11). There are no signs of inflammatory reaction in the dermis (Fig. 12).

Pathological changes were revealed b histological method in the layers of the skin, while maintaining its structure. In the studied specimens of the tentacles skin, thickening and thickening of the epidermis, small-focal polymorphocellular infiltrates, visual disturbances of the microcirculatory bed, formation of microabscesses and growth of sebaceous glands in the dermis were established. The detected changes indicate the course of the inflammatory process in the areas of the epidermis, dermis and hypodermis. 


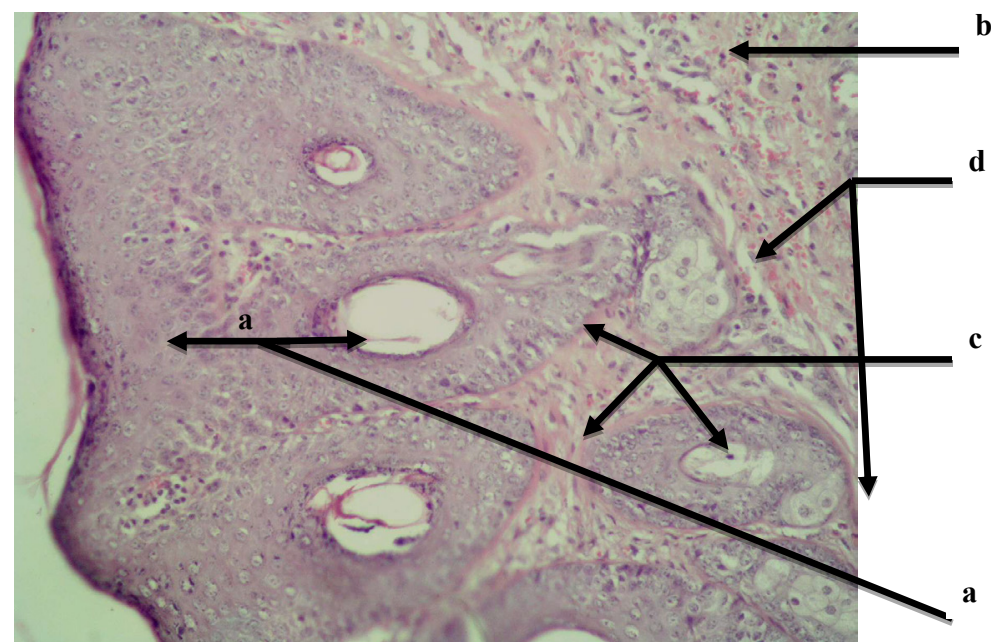

Fig. 4. The skin of an ill Guinea pig in the acute course: $\mathrm{a}$ - thickening of the epidermis; $\mathrm{b}$ - dermis; $\mathrm{c}$ - hair follicles; $\mathrm{d}$ - sebaceous glands. Hematoxylin and eosin. EG. 10, vol. 20

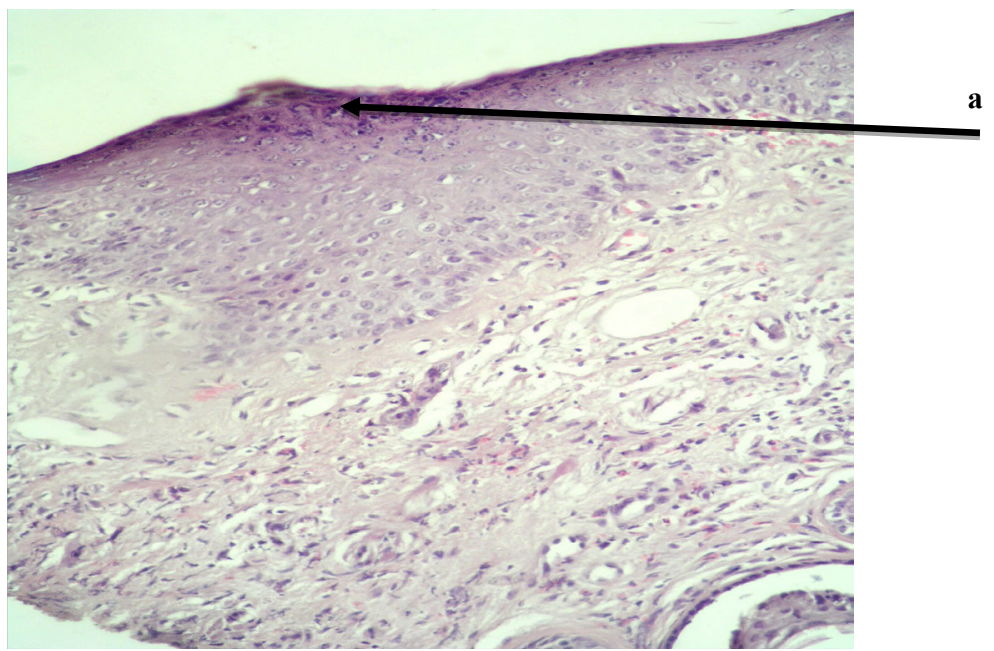

Fig. 5. The skin of an ill Guinea pig in the acute course:

$\mathrm{a}-$ Thickening of the stratum corneum of the epidermis. Hematoxylin and eosin. EG. 10, vol. 20

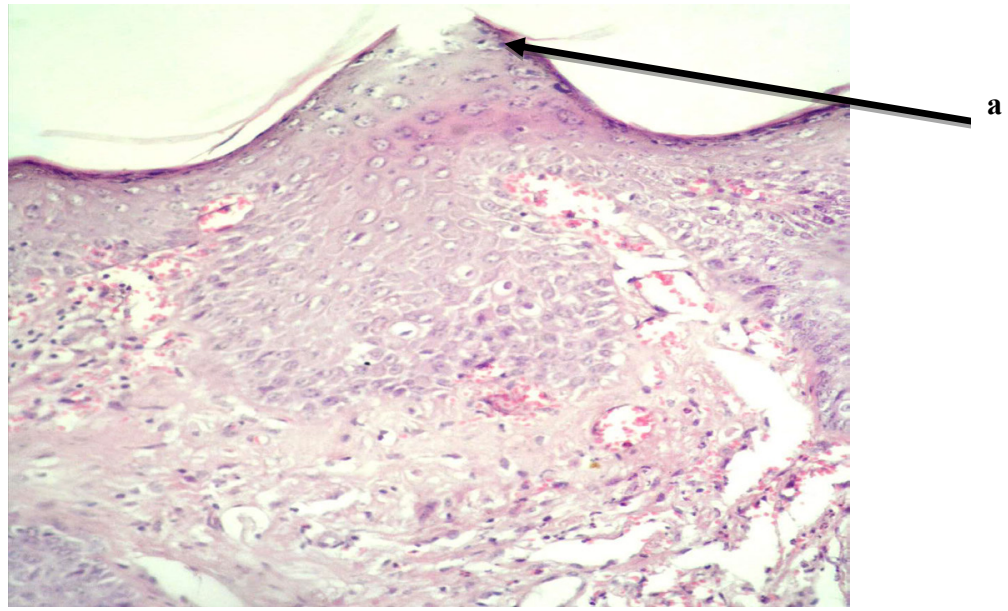

Fig. 6. The skin of an ill Guinea pig in the acute course:

a-Microcrack of the upper layers of the epidermis. Hematoxylin and eosin. EG. 10, vol. 20 


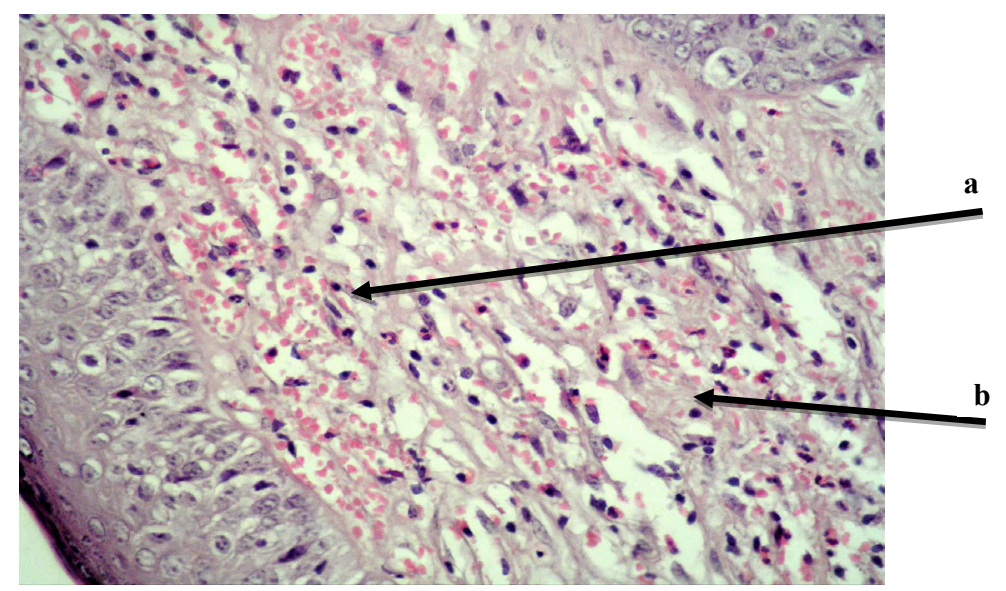

Fig. 7. The skin of an ill Guinea pig in the acute course:

$\mathrm{a}$ - Expansion of blood capillaries; $\mathrm{b}$ - Inflammatory infiltration in the dermis.

Hematoxylin and eosin. EG. 10, vol. 40

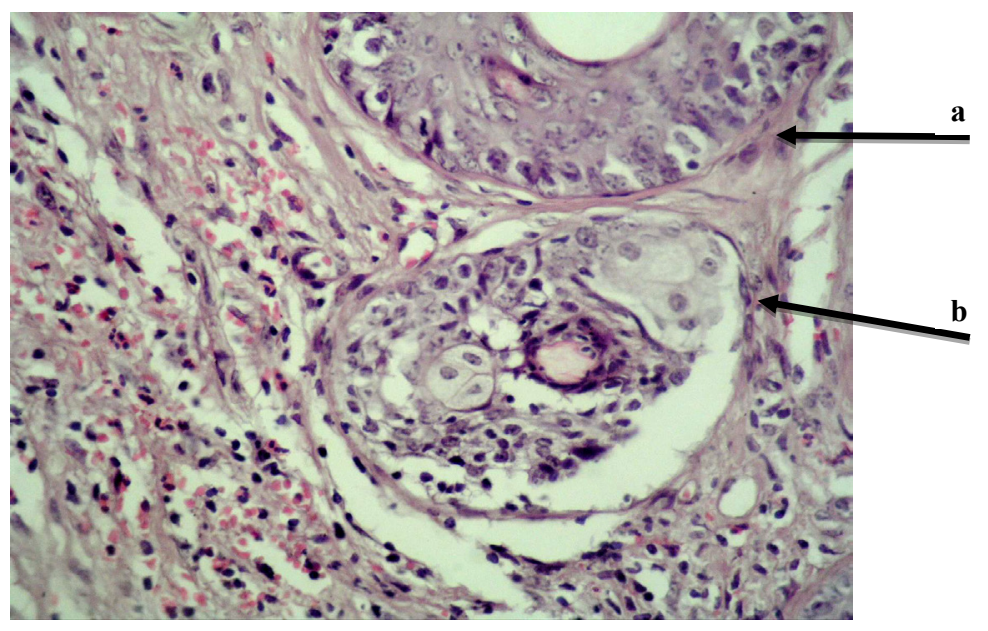

Fig. 8. The skin of an ill Guinea pig in the acute course:

$\mathrm{a}$ - swelling of the hair follicle of epithelium; $\mathrm{b}$ - polymorphonuclear cell infiltrates in the dermis. Hematoxylin and eosin. EG. 10, vol. 40

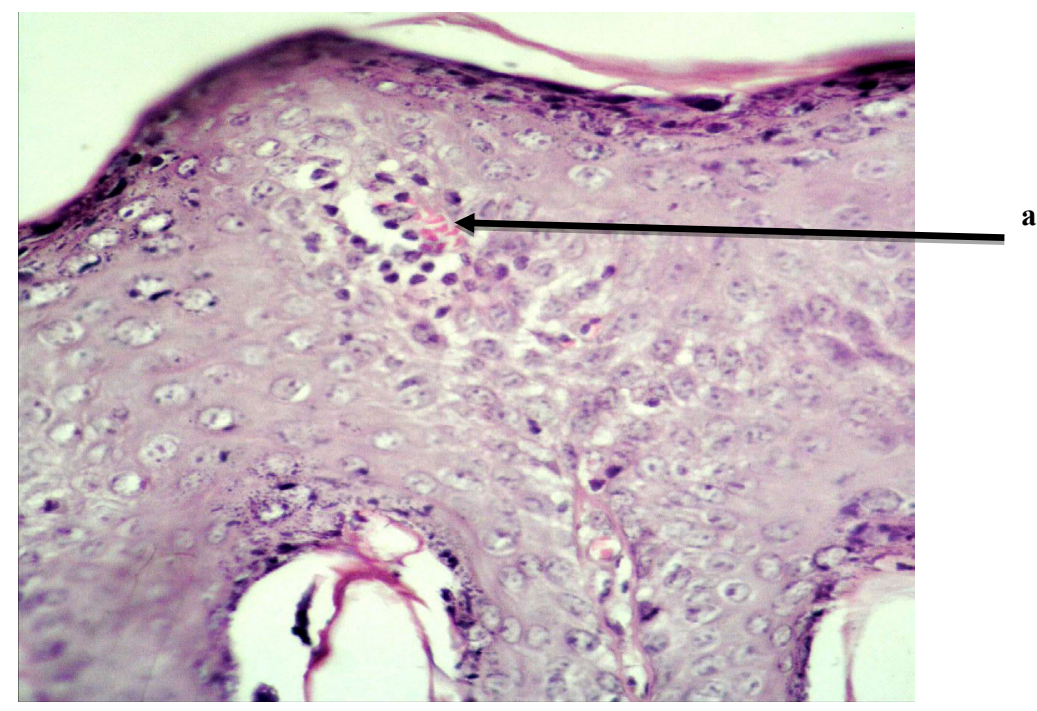

Fig. 9. The skin of an ill Guinea pig in the acute course: a - Formation of microabscess.

Hematoxylin and eosin. EG. 10, vol. 40 


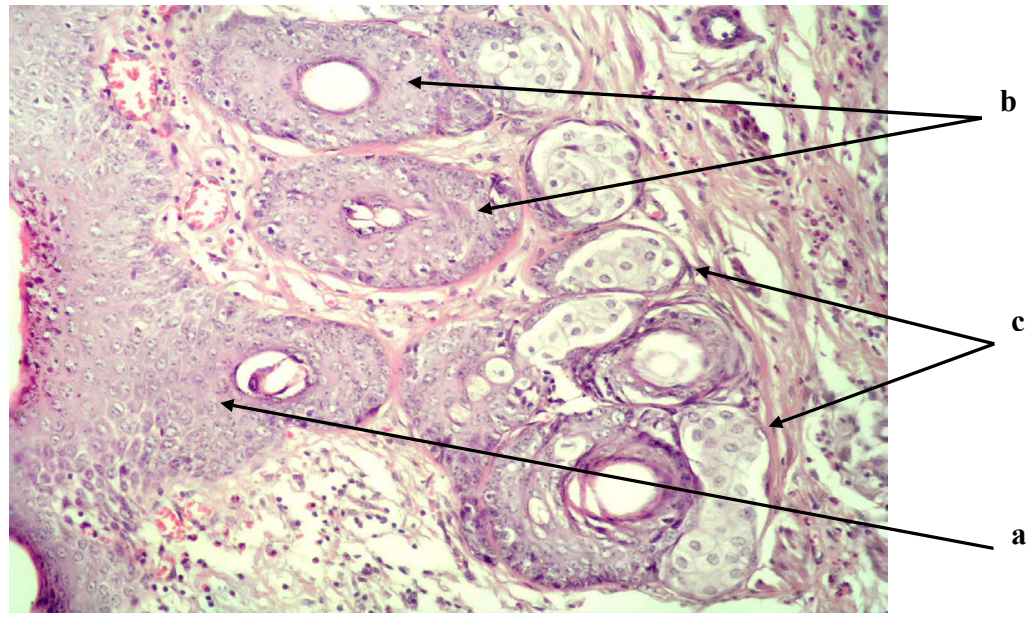

Fig. 10. The skin of anill Guinea pig in the acute course:

$\mathrm{a}$ - thickening of the epidermis; $\mathrm{b}$ - hyperplasia of the hair follicle epithelium; $\mathrm{c}-$ growth of sebaceous glands. Hematoxylin and eosin. EG. 10, vol. 20

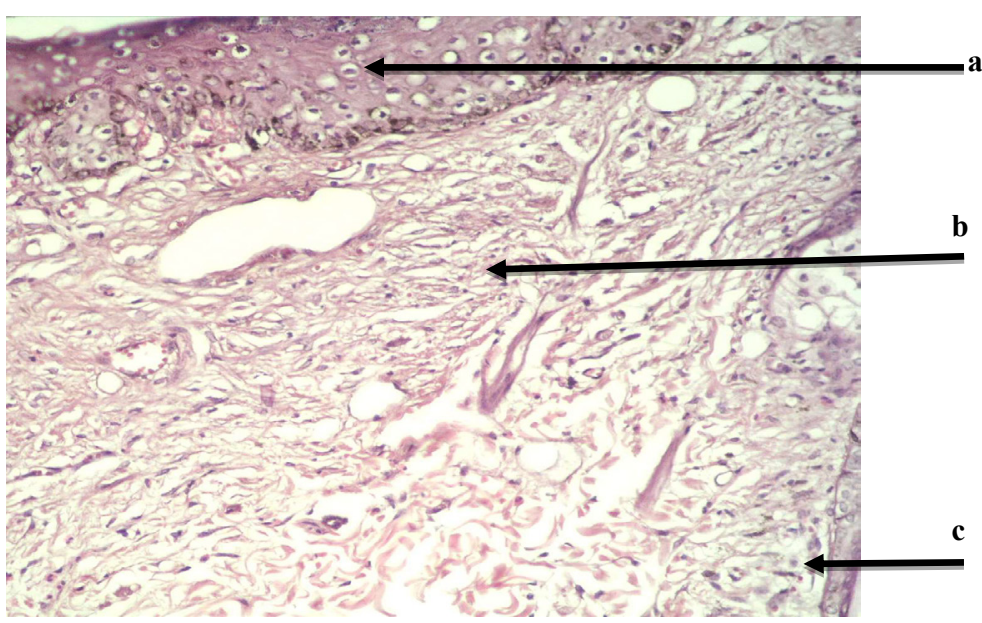

Fig. 11. The skin of an ill Guinea pig in the regeneration stage: a - epidermis; b-dermis; c-hypodermis. Hematoxylin and eosin. EG. 10, vol. 10

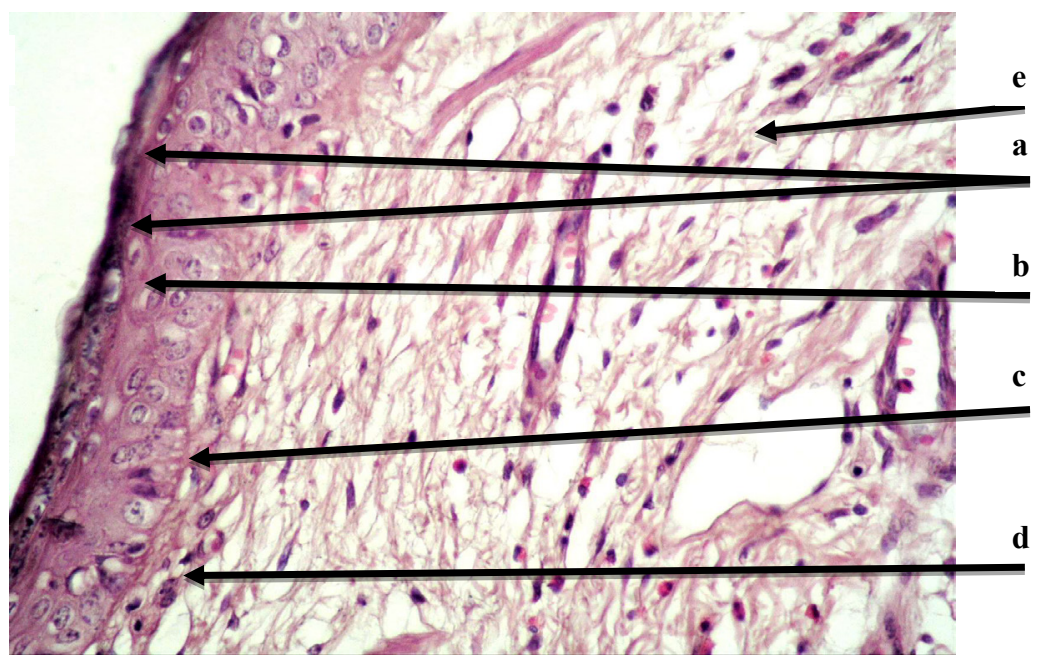

Fig. 12. The skin of an ill Guinea pig in the stage of regeneration: $\mathrm{a}$ - horny layer; $\mathrm{b}$ - granular layer; $\mathrm{c}$ - spiked layer; $\mathrm{d}$ - basal membrane; $\mathrm{e}$ - derma. Hematoxylin and eosin. EG. 10, vol. 40 


\section{Discussion}

Histological studies were performed to determine pathomorphologic changes in all skin. It was found that not only epidermis is affected. Papillary dermis, hair follicles, sebaceous glands and hypodermis exhibit signs of inflammation.

It is accompanied by lymphoid, histiocytes and leukocyte infiltration. These studies are shown changes in the epidermis [18]. Epidermis studies were conducted by native microscopy of skin scales. Therefore, biopsy and study of all layers of the skin has more informative value.

Also most authors describe the cause of microsporia immunodeficiency states of the organism. It is advisable to research the blood of patients to determine the immune status. Determination of WBC count, lymphocytes and the activity of T-killers, T-helpers and T-suppressos give an opportunity to assess the immune activity of organism in microsporia.

Description of pathomorphological changes in skin enables solution of complex treatment. Histologic changes suggest that antifungal agent is not enough for conducting treatments. Drugs for treatment should have a wide range of effects and prevent possible complications by secondary pyodermy [19].

Study limitation. A limitation of the study is the fact that the structure of the skin is multilayered. Also at the base of the epidermis are developing new cells that migrate upwards. According, at different stages of fattening, the rate of skin recovery occurs individually in each of the animals studied [20, 21]. However, it does not affect the course of the disease and the manifestation of its pathomorphologic changes.

Prospects for further research. Development and testing of the complex drug "Micromar" for the treatment of microsporia and immunostimulant "Biogluk", which in combination will provide quality treatment of the disease, prevent complications of bacterial flora, improve skin barrier function and stimulate regenerative processes, which in turn will accelerate the period of recovery.

\section{Conclusion}

With microsporia, not only superficial, but also deep layers of the skin are affected. The skin of patients with guinea pig microsporia experiences pathological changes that are characterized by an inflammatory process. Inflammatory processes occur in the epidermis, dermis and hypodermis.The skin of sick animals retains its structure, but its barrier function is lost due to pathomorphological changes.

In patients with microsporia, there were changes in the morphological composition of the skin, which were characterized by thickening and keratinization of the epidermis, small focal polymorphic cell infiltrates occurred, there was a violation of the microvasculature and the formation of micellar formations.

Long-term effects of the pathological process during the course of microspores can provoke the development of chronic dermatitis with skin sclerosis.

\section{Conflict of interests}

The authors declare that they have no conflicts of interest.

\section{References}

[1] Peterson, S. (2008). Kozhnye bolezni koshek. Moscow: Akvariui-Print, 168.

[2] Donnik, I. M., Bezborodova, N. A. (2009). Monitoringovye issledovaniia mikotoksinov v kormakh i kormovom syre v Uralskom regione. Agrarnyi vesnik Urala, 8, 87-89.

[3] Kotsiumbas, H. I., Kotsiumbas, I. Ya., Shchebentovska, O. M., Dankovych, R. S., Zaitsev, O. O. (2010). Morfolohichni osoblyvosti shkiry ta volosa riznykh vydiv tvaryn ta liudyny v aspekti sudovo-veterynarnoi medytsyny. Lviv: Afisha, 134.

[4] Domnitskii, I. Iu. (2009). Patologicheskaia diagnostika vistseralnogo mikoza. Saratov, 43.

[5] Horalskyi, L. P., Khomych, V. T., Kononskyi, O. I. (2005). Osnovy histolohichnoi tekhniky i morfofunktsionalni metody doslidzhen u normi ta pry patolohii. Zhytomyr: Polissia, 288.

[6] ZHenikhova, N. I., Badova, O. V., Nikitin, A. P., Badova, N. D. (2014). Klinicheskie i posmertnye osobennosti endogennykh gribkovykh infektsii u ekzoticheskikh zhivotnykh, ptits i reptilii. Moscow. 
[7] Mazankova, L. N., Korsunskaia, Y. M., Tamzarova, O. B. (2006). Osobenosty techenyia mykrosporyy u detei. Praktyka pediatra, 5, 39-42.

[8] Kulko, A. B., Dreval, P. (2010). Yeasts and mycelial fungi in lung cavities of tuberculosis patients. 20th European Congress of Clinical Microbiology and Infectious Diseases. Vienna, 16 (2).

[9] Pototskyi, M. K. (2001). Osnovy histopatolohichnoi. Kyiv, 66.

[10] Kulko, A. B. (2012). Spektr vozbuditelei glubokikh mikozov cheloveka. Redkie bolezni i sovremennye vozmozhnosti terapii, $3,55-61$.

[11] Steven, I., Scott, M. A. (2008). Fundamental veterinary clinical pathology. Second Edition. Blackwell Publishing, 934.

[12] Urbanovych, P. P., Pototskyi, M. K., Hevkan, I. I., Zon, H. A., Borysevych, B. V., Papchenko, I. V. et. al. (2008). Patolohichna anatomiia tvaryn. Kyiv: Vetinform, 896.

[13] Potekaev, N. N. (2000). Mikrosporiia. RMZH, 4, 189.

[14] Kuhar, E. V., Panchenko, N. A., Sharipova, A. M., Glotova, T. I. (2014). Kulturalno-morfologicheskie, biohimicheskie svoystva i molekulyarno-geneticheskaya harakteristika Microsporum canis. Journal of Small Animal Practice, 5, $21-24$.

[15] Kirk, R., Bonagura, Dzh. (2014). Sovremennyi kurs veterinarnoi meditsiny. Moscow: Akvarium- Print, 1376.

[16] Genicheva, N. I., Badova, O. V., Abramov, A. V., Shilov, E. N.(2013). Klinicheskoe proiavlenie zigomikoza verbliudov pri vskrytii. Agrarnyi vesnik Urala, 12, 29-31.

[17] Merkulov. G. A. (1969). Kurs patologogistologicheskoi tekhniki. Leningrad: Meditsina, 423.

[18] Ascioglu, S., Rex, J. H., de Pauw, B., Bennett, J. E., Bille, J. et. al. (2002). Defining Opportunistic Invasive Fungal Infections in Immunocompromised Patients with Cancer and Hematopoietic Stem Cell Transplants: An International Consensus. Clinical Infectious Diseases, 34 (1), 7-14. doi: http://doi.org/10.1086/323335

[19] Aiziatulov, R. F. (2015). Klinicheskie proiavleniia i printsipy lecheniia gribkovykh boleznei kozhi. Zhurnal dermatologii i kosmetologii im. M.O. Torsueva, 1-2 (34), 7-11.

[20] Filimonkova, N. N., Kokhan, M. M.,Shherbakova, N. V., Budumian, T. M., Panova, E. O., Mokhnashina, O. V., Kolesnik, V. V. (2005). Morfo-biologicheskie osobennosti vozbuditelei mikrosporii i klinicheskoe techenie zabolevaniia (analiticheskii obzor). Uralskii meditsinskii zhurnal, 3, 29-43.

[21] Drozdova, L. I., Zhenikhova, N. I., Badova, O. V. (2014). Patomorfologicheskie izmeneniia v organakh i tkaniakh zhivotnykh i ptits pri mikozakh vyzyvaemykh plesnevymi gribami. Agrarnyi vesnik Urala, 12 (130), 17-20. 